\title{
Implikasi Corporate Governance, Investment Opportunity Set, Firm Size, Dan Leverage Terhadap Earnings Quality
}

\author{
Augustpaosa Nariman dan Margarita Ekadjaja \\ Fakultas Ekonomi Universitas Tarumanagara, Jakarta \\ Email:augustpaosa@fe.untar.ac.id dan margaritae@fe.untar.ac.id
}

\begin{abstract}
Profit of a company is used by creditor and investor to evaluate the performance of the management, estimate earnings power, and to predict future profit. Earning qualityis measured from the accrual. A company with high accrual is indicating that the quality of company profit is low, and vice versa. According to Chan,et al. (2001) profit quality in the financial report will increase company value which is reflected in the stock return. Purpose of the this research is to understand the impact of variable ofinstitutional shareholding, board size, board independence, investment opportunity set, firm size, and leverageto theearnings quality. This research is using manufacturing industry that listed in the Indonesian stock exchange during the period of 20132016, sample is taken using purposive samplin technique.Based on analysis result and research is done using double linear regression with the eviews 9.0 software, we can conclude that there is a significant positive influence between institutional shareholding, board size, board independence, investment opportunity set, firm size, and leverageto the earnings quality. While leverage has insignificant influence to the earnings qualitymeasured with Discretionary Accruals (DACCR).
\end{abstract}

Key Words: institutional shareholding, board size, board independence, investment opportunity set, firm size, leverage, earnings quality

\begin{abstract}
Abstrak: Laba digunakan kreditur dan investor untuk mengevaluasi kinerja manajemen, memperkirakan earnings power, dan untuk memprediksi laba di masa yang akan datang. Kualitas laba (earning quality) diukur dengan akrual. Perusahaan dengan akrual yang tinggi menunjukkan laba perusahaan berkualitas rendah, demikian juga sebaliknya. Menurut Chan,et al. (2001) kualitas laba yang terkandung dalam pelaporan keuangan akan meningkatkan nilai perusahaan yang tercermin dalam return saham. Tujuan penelitian ini adalah mengetahui pengaruh variabel institutional shareholding, board size, board independence, investment opportunity set, firm size, dan leverage terhadap earnings quality. Penelitian ini menggunakan industri manufaktur yang terdaftar di Bursa Efek Indonesia tahun 2013-2016, sample diambil menggunakan teknik purposive sampling.

Hasil analisis dan pengujian yang telah dilakukan menggunakan regresi linier berganda dengan bantuan aplikasi software eviews 9.0 dapat disimpulkan bahwa terdapat pengaruh positif signifikan antara institutional shareholding, board size, board independence, investment opportunity set, firm size, dan leverage dengan earnings quality. Sedangkan pengaruh tidak signifikan antara leverage terhadap earnings quality diukur dengan Discretionary Accruals (DACCR).
\end{abstract}

Kata kunci: institutional shareholding, board size, board independence, investment opportunity set, firm size, leverage, earnings quality 


\section{PENDAHULUAN}

Laporan keuangan menyajikan informasi mengenai posisi keuangan, perubahan posisi keuangan serta kinerja suatu perusahaan. Informasi tersebut akan digunakan sebagai acuan dalam pengambilan keputusan bagi pemakainya (Fitriana dan Fadhlia, 2016).Menurut Suwardjono (2008:464) dalam Fitriana dan Fadhlia (2016) salah satu informasi penting yang disajikan di laporan keuangan adalah laba perusahaan. Laba merupakan keuntungan yang diperoleh oleh perusahaan dari kegiatan menjual barang atau jasanya. Laba dapat digunakan sebagai kebijakan pemberian deviden, memprediksi kinerja, dasar pengambilan keputusan, dasar pengenaan penghasilan kena pajak, serta pedoman dalam investasi (Harnanto, 2003:444 dalam Fitriana dan Fadhlia, 2016).

Penyajian informasi mengenai laba perusahaan merupakan hal yang penting karena hal tersebut dapat menggambarkan kinerja suatu perusahaan (Meriewaty dan Setyani, 2005: 278). Baik kreditor maupun investor, menggunakan laba untuk: menilai kembali kinerja manajemen, memprediksi laba masa depan, serta memperkirakan earnings power (Siallagan dan Machfoedz, 2006: 2).

Kualitas laba merupakan faktor yang sangat penting bagi pengguna informasi keuangan seperti peneliti, analis keuangan, investor, maupun kreditor. Kualitas laba dapat diragukan apabila laba yang disajikan dalam laporan keuangan tidak sesuai dengan kondisi ekonomis perusahaan.Kualitas laba dipengaruhi oleh banyak faktor. Menurut Wardhani (2009: 2), faktor-faktor yang memengaruhi kualitas laba dibagi menjadi faktorfaktor internal dan eksternal. Faktor-faktor eksternal yang memengaruhi kualitas laba antara lain: proteksi bagi investor dan standar akuntansi yang berlaku di suatu negara. Selain faktor-faktor eksternal tersebut, terdapat juga faktor-faktor internal yang memengaruhi kualitas laba, antara lain: implementasi corporate governance dan kualitas audit.Siallagan dan Machfoedz (2006: 15) juga mendukung pendapat Wardhani (2009) bahwa mekanisme corporate governance memengaruhi kualitas laba. Mekanisme corporate governance yang diteliti terdiri dari kepemilikan manajerial, proporsi jumlah anggota dewan komisaris independen, dan keberadaan komite audit.Kualitas laba juga dapat dipengaruhi oleh investment opportunity set (IOS). IOS merupakan kesempatan perusahaan untuk tumbuh. IOS dijadikan sebagai dasar untuk menentukan klasifikasi pertumbuhan perusahaan di masa depan (Novianti, 2012: 2). Berdasarkan penelitian yang dilakukan Rachmawati dan Triatmoko (2007: 15) didapatkan hasil bahwa IOS memiliki pengaruh yang signifikan terhadap kualitas laba.

Firm size merupakan ukuran besar kecilnya perusahaan. Beberapa penelitian, seperti penelitian Sadiah dan Priyadi (2015: 17) menyatakan bahwa ukuran perusahaan atau firm size memiliki pengaruh yang signifikan terhadap kualitas laba. Warianto dan Rustiti (2013: 11) juga memiliki hasil bahwa ukuran perusahaan berpengaruh negatif signifikan terhadap discretionary accruals. Dengan kata lain, ukuran perusahaan berpengaruh positif terhadap earnings quality.

Leverage juga dapat memengaruhi kualitas laba. Leverage adalah variabel untuk mengetahui seberapa besar hutang perusahaan membiayai aset perusahaan. Berdasarkan penelitian Warianto dan Rustiti (2013: 12) diketahui bahwa terdapat pengaruh negatif signifikan antara leverage terhadap kualitas laba.

Penelitian ini diarahkan untuk memperluas bidang penelitian dengan mempertimbangkan sebuah model empiris (institutional shareholding, board size, board independence, investment opportunity set, firm size, dan leverage institutional shareholding, board size, board independence, investment opportunity set, firm size, dan 
leverage) pengaruhnya terhadap earning quality. Diharapkan dengan penambahan variabel penelitian dapat menghasilkan temuan empiris yang berbeda. Dengan demikian judul penelitian adalah Proksi yang digunakan untuk mengukur kualitas laba dalam penelitian ini adalah discretionary accruals. Discretionary accruals dihitung dengan menggunakan modified Jones' model karena model ini dianggap lebih baik dibandingkan dengan model lainnya (Dechow et al., 1995 dalam Siallagan dan Machfoedz, 2006: 10).

Rumusan penelitiansebagai berikut: (1) Apakah mekanisme corporate governance (institutional shareholder, board size, board independence berpengaruh terhadap earnings quality?; (2) Apakah investment opportunity set berpengaruh terhadap earnings quality?; (3) Apakah firm size berpengaruh terhadap earnings quality?; (4) Apakah leverage berpengaruh terhadap earnings quality?

\section{KAJAIN TEORI}

\section{Earnings Quality}

Menurut Bandi (2009) dalam Wulansari (2013: 5), laba yang merupakan bagian dari laporan keuangan harus berkualitas untuk dapat menjadi informasi yang bermanfaat.Laba dikatakan berkualitas apabila laba tersebut mampu mencerminkan sustainable earnings di masa mendatang, yang ditentukan oleh komponen akrual dan kas, serta dapat menggambarkan kinerja keuangan perusahaan yang sebenarnya (Djamaluddin, 2008 dalam Wulansari, 2013: 5).Dechow, Ge, dan Schrand(2010: 344) mendefinisikan kualitas laba sebagai berikut: "Higher quality earnings provide more information about the features of a firm's financial performance that are relevant to a specific decision made by a specific decision-maker."

Dari definisi di atas, terdapat tiga hal yang ditekankan oleh Dechow, Ge, dan Schrand (2010).Pertama, kualitas laba tergantung pada informasi yang relevan dalam membuat keputusan.Dengan demikian, pendefinisian kualitas laba di atas hanya dalam konteks model keputusan tertentu.Kedua, kualitas dari angka laba yang dilaporkan dilihat dari apakah informasi tersebut menggambarkan kinerja keuangan suatu perusahaan.Ketiga, kualitas laba secara bersama-sama ditentukan oleh relevansi dari kinerja keuangan yang mendasari keputusan.

Penman dan Cohen (2003) dalam Setianingsih (2016: 2) mengungkapkan bahwa apabila laba dalam periode saat ini dapat menjadi indikator yang baik untuk laba periode mendatang, atau berhubungan secara kuat dengan arus kas operasi di periode mendatang (future operating cash flow), maka laba tersebut dapat dikatakan memiliki kualitas yang baik. Dechow dan Schrand (2004) dalam Warianto dan Rustiti (2013: 4-5) menyebutkan bahwa laba yang berkualitas merupakan laba yang memiliki tiga karakteristik sebagai berikut: 1) Secara akurat mampu mencerminkan kinerja operasi perusahaan saat ini, 2) Mampu memberikan indikator yang baik mengenai kinerja perusahaan di masa depan, dan 3) Dapat menjadi ukuran yang baik untuk menilai kinerja perusahaan.

Dechow, et.al (2010: 350-376) mengklasifikasikan proksi dari kualitas laba ke dalam tiga kategori utama yaitu: 1) Sifat laba (properties of earnings) yangmeliputi: persistensi laba (earnings persistence), ukuran besarnya akrual (magnitude of accruals), nilai sisa model akrual (residual from accrual models), perataan laba (earnings smoothness), dan ketepatan pengakuan rugi (timely loss recognition). 2) Respon investor terhadap laba (investor responsiveness to earnings) yang meliputi: Earnings Response Coefficient $(E R C) .3)$ Indikator eksternal dari salah saji laba (indicators external of earnings 
misstatement) yang meliputi: Accounting and Auditing Enforcement Releases (AAERs), pernyataan kembali (restatements), dan ketidakefisienan prosedur internal kontrol berdasarkan Sarbanes Oxley Act (internal control procedure deficiencies reported under the Sarbanes Oxley Act).

\section{a. Mekanisme Corporate Governance}

Pengertian corporate governance yang dijelaskan Muid (2009: 96) adalah sebagai berikut:Seperangkat peraturan yang mengatur hubungan antara pemegang saham, pengurus (pengelola) perusahaan, pihak kreditur, pemerintah, karyawan, serta para pemegang kepentingan internal dan eksternal lainnya yang berkaitan dengan hak-hak dan kewajiban mereka, atau dengan kata lain suatu sistem yang mengendalikan perusahaan.

Penelitian oleh Houqe, et al. (2010: 2-4) dilakukan dengan membagi mekanisme corporate governance menjadi management shareholding, institutional shareholding, government shareholding, board size, board independence, audit quality, dan family control. Muid (2009: 96-97) menggunakan kepemilikan manajerial, dewan komisaris, komite audit, dan kepemilikan institusional sebagai mekanisme corporate governance dalam penelitiannya. Penelitian ini mengambil tiga mekanisme corporate governance dari tujuh mekanisme corporate governance yang diteliti oleh Houqe, et al. (2010). Mekanisme corporate governance yang digunakan dalam penelitian ini adalah institutional shareholding, board size, dan board independence.

\section{b. Institutional Shareholding}

Listiyani (2003) dalam Dewi (2008: 50) menjelaskan definisi kepemilikan institusional sebagai berikut: "Kepemilikan institusional adalah proporsi saham yang dimiliki oleh pihak institusi pada akhir tahun yang diukur dalam prosentase". Scott (2000) dalam Dewi (2008: 50) menyatakan tingkat kepemilikan institusional yang tinggi akan mampu membatasi perilaku oportunistik manajer melalui upaya-upaya pengawasan yang lebih intensif.Pernyataan di atas didukung oleh Boediono (2005: 175) yang mengatakan bahwa:Melalui mekanisme kepemilikan institusional, efektivitas pengelolaan sumber daya perusahaan oleh manajemen dapat diketahui dari informasi yang dihasilkan melalui reaksi pasar atas pengumuman laba. Kepemilikan institusional memiliki kemampuan untuk mengendalikan pihak manajemen melalui proses monitoring secara efektif sehingga mengurangi tindakan manajemen melakukan manajemen laba. Persentase saham tertentu yang dimiliki oleh institusi dapat memengaruhi proses penyusunan laporan keuangan yang tidak menutup kemungkinan terdapat akrualisasi sesuai kepentingan pihak manajemen.

Lang dan McNichols (1997), Rajgopal (1999), Bushee (1998), Porter (1992), Rajgopal dan Venkatachalam (1998), dan Pratana P. Midiastuty dan Mas'ud Mahfoedz (2003) dalam Boediono (2005: 175) memiliki kesimpulan penelitian yang secara keseluruhan adalah kepemilikan institusional memiliki kemampuan untuk memengaruhi tindakan manajemen laba. Kepemilikan institusional dapat diukur dengan menggunakan indikator persentase jumlah saham yang dimiliki pihak institusional dari seluruh jumlah saham perusahaan.

Beiner (2003) dalam Rupilu (2011: 110) mendefinisikan kepemilikan institusional sebagai jumlah persentase hak suara yang dimiliki oleh institusi. Dalam penelitian ini diukur dengan menggunakan indikator persentase jumlah saham yang dimiliki institusi dari seluruh modal saham yang beredar. 


\section{$\Sigma$ shares held by financial institution \\ INST $=\quad$ E ordinary shares \\ c. Board Size}

Houqe, et al. (2010: 5) menjelaskan board size atau ukuran dewan adalah jumlah personel dewan direksi yang terdapat dalam suatu perusahaan.Houqe, et al. (2010: 3) menjelaskan bahwa board size merupakan elemen penting di dalam karakteristik dewan yang dapat memiliki dampak pada manajemen laba. Harper (2007) dalam Nathania (2014: 77) mengatakan bahwa akan lebih sulit bagi seorang CEO untuk memimpin dan mengendalikan dewan seiring dengan bertambahnya jumlah dewan di atas 10 anggota. Kesempatan setiap individu dalam dewan untuk memberikan pengaruh dalam pengambilan keputusan menjadi lebih terbatas dan setiap pertemuan yang dilakukan akan menjadi lebih tidak terkendali.

Goodstein, Gautam, dan Boeker (1994) dalam Houqe, et al. (2010: 3-4) serta Nathania (2014: 77) mengatakan bahwa walaupun dengan jumlah keanggotaan dewan yang lebih banyak dapat meningkatkan jumlah variasi keahlian dan kemampuan dewan, ukuran dewan yang lebih kecil antara empat hingga enam anggota akan lebih efektif dalam membuat keputusan yang tepat waktu. Hal itu didukung oleh Forbes dan Millike (1999) dalam Nathania (2014: 77) yang berpendapat bahwa seringkali, seiring dengan banyaknya jumlah anggota dewan akan lebih sulit untuk melakukan koordinasi karena jumlah interaksi yang lebih banyak diantara para anggota.

Penelitian Houqe, et al. (2010: 5) menjelaskan bahwa board size (BSIZE) atau ukuran dewan adalah jumlah personel dewan direksi yang terdapat dalam suatu perusahaan.

\section{d. Board Independence}

\section{$B S I Z E=\Sigma$ directors on the board}

Charlie Weir (2000) dalam Wulandari (2006: 125) menganggap dewan komisaris yang independen sama dengan direktur noneksekutif. Direktur noneksekutif ini adalah orang-orang yang tidak memiliki jabatan eksekutif dalam perusahaan dan juga tidak memiliki hubungan dengan perusahaan itu atau kepentingan di dalamnya sebelum mereka diangkat sebagai direktur. Ada peran yang dapat memediasi hubungan antara manajer, auditor, dan pemegang saham. Fama dan Jensen (1983) dalam Wulandari (2006: 125) menyatakan bahwa Non-executive director (komisaris independen) dapat bertindak sebagai penengah dalam perselisihan yang terjadi di antara para manajer internal dan mengawasi kebijaksanaan direksi serta memberikan nasihat kepada direksi.

Dewan komisaris independen merupakan tingkat tertinggi dari sistem pengelolaan internal perusahaan. Peranan dewan komisaris independen juga diharapkan dapat meningkatkan kualitas laba dengan membatasi tingkat manajemen laba melalui fungsi monitoring atas laporan keuangan (Rupilu, 2011: 110). Fama (1980) dalam Wulandari (2006: 125) berpendapat bahwa fungsi utama dari direktur noneksekutif adalah untuk memastikan bahwa direktur eksekutif melaksanakan atau mengikuti kebijakan konsisten dengan kepentingan pemegang saham.

Board Independence adalah puncak dari sistem pengelolaan internal perusahaan, peranan dewan komisaris independen juga diharapkan dapat meningkatkan kualitas laba dengan membatasi tingkat manajemen laba melalui fungsi monitoring atas laporan keuangan (Rupilu, 2011: 110). Houqe, et al. (2010: 5) memberikan perhitungan proporsi dewan komisaris independen (BIND) sebagai berikut: 


\section{$B I N D=\frac{\sum \text { non executive directors in the board }}{\Sigma \text { directors in the board }}$}

\section{e. Investment Opportunity Set}

Myers 1977 dalam Irma (2011) dalam Wulansari (2013: 7-8) mengartikan investment opportunity set sebagai nilai sekarang dan pilihan perusahaan untuk membuat investasi di masa mendatang. Wulansari (2013) lebih lanjut menjelaskan bahwa secara umum investment opportunity set menggambarkan tentang luasnya kesempatan atau peluang investasi bagi suatu perusahaan, namun sangat tergantung pada pilihan expenditure perusahan untuk kepentingan di masa yang akan datang. Perusahaan dengan IOS yang tinggi cenderung dinilai positif oleh investor karena lebih memiliki prospek keuntungan di masa yang akan datang (Warianto dan Rustiti, 2013: 6).Terdapat beberapa proksi yang digunakan untuk memahami proyek investment opportunity set dalam bidang akuntansi yang dapat diklasifikasikan menjadi tiga jenis utama. Menurut Kallapur dan Tomberly (2001) dalam Sadiah dan Priyadi (2015: 8-9) tiga proksi investment opportunity set yaitu: 1) Proksi berdasarkan harga (price based proxies), 2) Proksi berdasarkan investasi, dan 3) Proksi berdasarkan varian (variance measurements).

Kallapur dan Tomberly (2001) dalam Rachmawati dan Triatmoko (2007: 6) menjelaskan pengaruh IOS terhadap earnings quality sebagai berikut: "Kesempatan investasi perusahaan merupakan komponen penting dari nilai pasar. Karena tingkat investment opportunity set perusahaan berpengaruh pada cara pandang manajer, pemilik, investor, dan kreditor terhadap perusahaan." Hasil penelitian Wah (2002) dalam Warianto dan Rustiti (2013: 6) mengatakan bahwa meskipun suatu perusahaan memiliki IOS yang tinggi, manajer cenderung memanipulasi discretionary accruals sehingga kualitas laba perusahaan tersebut menjadi rendah.

Investment opportunity set merupakan nilai sekarang dan pilihan perusahaan untuk membuat investasi di masa mendatang (Myers, 1977 dalam Wulansari, 2013: 8). Penelitian Warianto dan Rustiti (2013: 8) menyatakan investment opportunity set akan diukur melalui market value to book value of assets ratio (MVBVA) yang dijabarkan sebagai berikut:

$$
M V B V A=\frac{\sum \text { assets }- \text { Eequity }+(\text { OS } x \text { Closed Price })}{\Sigma \text { assets }}
$$

Keterangan: $\quad$ OS $=$ Total outstanding shares

\section{f. Firm Size}

Ukuran perusahaan adalah skala besar kecilnya perusahaan (Brigham dan Houston, 2001 dalam Warianto dan Rustiti, 2013: 5). Suryani (2010) dalam Warianto dan Rustiti (2013: 5) menyebutkan bahwa publik akan melihat kinerja perusahaan yang ukurannya relatif besar. Oleh sebab itu, perusahaan tersebut akan lebih berhati-hati dalam melaporkan kondisi keuangannya, lebih menunjukkan keinformatifan informasi yang terkandung di dalamnya, dan lebih transparan sehingga perusahaan akan lebih sedikit dalam melakukan manajemen laba. Dengan kata lain, semakin besar ukuran suatu perusahaan, semakin tinggi juga kualitas labanya.

Sadiah dan Priyadi (2015: 11) menyebutkan bahwa firm size diukur dengan logaritma dari total aset. Semakin besar hasil perhitungan logaritma total aset tersebut, maka semakin besar pula ukuran perusahaan tersebut. Rumus untuk menghitung firm size : 


\section{SIZE $=$ Log of firm total assets}

\section{g. Leverage}

Leverage digunakan untuk menjelaskan kemampuan perusahaan dalam menggunakan aset dan sumber dana untuk memperbesar hasil pengembalian kepada pemiliknya (Wulansari, 2013: 12). Tarjo dan Prawesti (2003) dalam Rupilu (2011: 112) menjelaskan bahwa variabel ini menggambarkan proporsi antara kewajiban yang dimiliki dan seluruh kekayaan yang dimiliki. Rasio ini digunakan untuk mengukur kemampuan perusahaan untuk memenuhi kewajiban jangka pendek dan hutang jangka panjang dan sebagai variabel kontrol karena leverage merupakan salah satu mekanisme yang digunakan untuk mengurangi oportunistik manajemen. Wulansari (2013: 12) menyatakan bahwa tingginya leverage suatu perusahaan menyebabkan ketidakpercayaan investor atas laba yang dipublikasikan oleh perusahaan tersebut karena investor menganggap perusahaan akan lebih mengutamakan pembayaran hutang terhadap debtholders daripada pembayaran dividen. Dengan demikian semakin besar tingkat leverage maka semakin rendah kualitas laba suatu perusahaan (Dhaliwal, et al., 1991 dalam Wulansari, 2013: 12).

Tarjo dan Prawesti (2003) dalam Rupilu (2011: 112) menjelaskan bahwa variabel ini menggambarkan proporsi antara kewajiban yang dimiliki dan seluruh kekayaan yang dimiliki. Rasio ini digunakan untuk mengukur kemampuan perusahaan untuk memenuhi kewajiban jangka pendek dan hutang jangka panjang dan sebagai variabel kontrol karena leverage merupakan salah satu mekanisme yang digunakan untuk mengurangi oportunistik manajemen.

Secara matematis leverage ( $L E V$ ) dapat diformulasi sebagai berikut:

$$
L E V=\frac{\text { Total long term debt }}{\text { Total assets }}
$$

Pengembangan Model Penelitian. Earnings quality adalah seberapa jauh net income yang dilaporkan dalam laporan laba rugi berbeda dengan laba sesungguhnya. Institutional shareholding adalah proporsi saham yang dimiliki oleh pihak institusi pada akhir tahun yang diukur dalam prosentase. Board size adalah jumlah personel dewan direksi yang terdapat dalam suatu perusahaan. Board independence adalah orang-orang yang tidak memiliki jabatan eksekutif dalam perusahaan, dan juga tidak memiliki hubungan dengan perusahaan itu atau kepentingan di dalamnya sebelum mereka diangkat sebagai direktur. Investment opportunity set adalah nilai sekarang dan pilihan perusahaan untuk membuat investasi di masa mendatang. Firm size adalah skala besar kecilnya perusahaan. Leverage adalah rasio yang digunakan untuk mengukur kemampuan perusahaan untuk memenuhi kewajiban jangka pendek dan jangka panjang.

Rupilu (2011: 106) meyakini bahwa investor institusional punya kemampuan yang lebih baik dalam memonitor tindakan manajemen dibanding investor individual. Boediono (2005: 175) juga mengatakan bahwa hal ini dapat mengurangi tindakan manajemen untuk melakukan manajemen laba. Dengan kata lain, tingginya kepemilikan institusional mengurangi manajemen laba dan menaikkan kualitas laba. Oleh karena itu, rumusan hipotesis dalam penelitian ini adalah:

H1: Institutional shareholding berpengaruh signifikan terhadap earnings quality.

Goodstein, Gautam, dan Boeker (1994) dalam Houqe et al. (2010: 3-4) serta Nathania (2014: 77) mengatakan bahwa ukuran dewan yang lebih kecil akan lebih efektif dalam membuat keputusan yang tepat waktu. Forbes dan Millike (1999) dalam Nathania (2014: 77) mendukung pendapat tersebut dengan mengatakan bahwa semakin banyak 
jumlah anggota dewan, maka akan semakin sulit untuk melakukan komunikasi dan koordinasi kerja dari masing-masing anggota. Hal ini membuat dewan sulit untuk mengawasi tindakan manajemen sehingga dimungkinkan adanya tindakan manipulasi laba dari manajemen. Dengan kata lain, besarnya ukuran dewan akan meningkatkan manajemen laba dan menurunkan kualitas laba. Oleh karena itu, rumusan hipotesis dalam penelitian ini adalah:

$\mathbf{H}_{2}$ : Board size berpengaruh signifikan terhadap earnings quality.

Fama dan Jensen (1983) dalam Rupilu (2011: 104) mengatakan bahwa komisaris independen bertindak sebagai penengah perselisihan yang terjadi di antara para manajer serta menjadi pengawas dan penasihat direksi. Peranan dewan komisaris independen diharapkan menurunkan manajemen laba dan meningkatkan kualitas laba. Oleh karena itu, rumusan hipotesis dalam penelitian ini adalah:

$\mathrm{H}_{3}$ : Board independence berpengaruh signifikan terhadap earnings quality.

Kallapur dan Tomberly (2001) dalam Rachmawati dan Triatmoko (2007: 6) mengatakan bahwa IOS perusahaan memengaruhi cara pandang pemilik, investor, dan kreditor terhadap perusahaan. Wah (2002) dalam Warianto dan Rustiti (2013: 6) mengatakan bahwa meskipun suatu perusahaan memiliki IOS yang tinggi, manajer cenderung memanipulasi discretionary accruals sehingga kualitas laba perusahaan tersebut menjadi rendah. Oleh karena itu, rumusan hipotesis dalam penelitian ini adalah: $\mathrm{H}_{4}$ : Investment Opportunity Set berpengaruh signifikan terhadap earnings quality.

Dalam penelitiannya, Warianto dan Rustiti (2013: 5) menjelaskan bahwa semakin besar ukuran suatu perusahan, maka semakin besar juga aset milik perusahaan tersebut. Sadiah dan Priyadi (2015: 9) menyatakan bahwa seiring dengan besarnya ukuran suatu perusahaan, maka semakin baik pula tingkat kinerja keuangan perusahaan tersebut sehingga tidak diperlukan adanya manajemen laba. Selain itu, Suryani (2010) dalam Warianto dan Rustiti (2013: 5) juga mengatakan bahwa kinerja perusahaan dengan ukuran yang besar akan dilihat oleh publik, sehingga secara otomatis perusahaan akan lebih hatihati dalam menerbitkan laporan keuangannya dan laba yang disajikan dalam laporan keuangan akan memiliki kualitas yang baik. Oleh karena itu, rumusan hipotesis dalam penelitian ini adalah:

$\mathrm{H}_{5}$ : Firm size berpengaruh signifikan terhadap earnings quality.

Irawati (2012) dalam Sadiah dan Priyadi (2015: 9) serta Warianto dan Rustiti (2013:

6) mengatakan bahwa leverage digunakan untuk mengetahui berapa banyak aset perusahaan yang dibiayai hutang perusahaan. Harris dan Raviv (1990) dalam Warianto dan Rustiti (2015: 6) menjelaskan bahwa tingginya hutang menunjukkan prospek yang kurang baik di masa depan. Dengan demikian, tingginya leverage suatu perusahaan akan memiliki kecenderungan untuk melakukan manajemen laba dan menurunkan kualitas laba perusahaan tersebut. Oleh karena itu, rumusan hipotesis dalam penelitian ini adalah:

$\mathrm{H}_{6}$ : Leverage berpengaruh signifikan terhadap earnings quality.

\section{METODE}

Penelitian ini dirancang sebagai penelitian deskriptif dan verifikatif melalui pendekatan kuantitatif yang menggunakan data sekunder. Variabel yang akan diteliti terdiri dari institutional shareholding, board size, board independence, investment opportunity set, firm size, dan leverage. Variabel dependen atau variabel terikat dalam penelitian ini adalah earnings quality (Y). Variabel independen atau variabel bebas dalam penelitian ini adalah 
institutional shareholding $\left(\mathrm{X}_{1}\right)$, board size $\left(\mathrm{X}_{2}\right)$, board independence $\left(\mathrm{X}_{3}\right)$, investment opportunity set $\left(\mathrm{X}_{4}\right)$, firm size $\left(\mathrm{X}_{5}\right)$, leverage $\left(\mathrm{X}_{6}\right)$.

Rancangan penelitian yang dilakukan melalui metode eksplanatori dengan menggunakan sampel. Sumber data berasal dari data keuangan perusahaan-perusahaan manufaktur yang terdaftar di BEI periode 2013-2016, dengan indikator earnings quality yang terdiri dari : institutional shareholding, board size, board independence, investment opportunity set, firm size, dan leverage.

a. Variabel Dependen

Variabel dependen (X1) merupakan variabel yang dipengaruhi oleh variabel lain. Variabel dependen dalam penelitian ini adalah earnings quality. Variabel ini diukur dengan menggunakan proksi discretionary accrual. Discretionary accrual digunakan untuk menunjukkan apakah perusahaan telah melaporkan laba sesuai dengan kenyataan atau tidak. Rachmawati dan Triatmoko (2007:9) menggunakan rumus Modified Jones Model.

b. Variabel Independen

Variabel independen dalam penelitian ini adalah institutional shareholding, board size, board independence, investment opportunity set, firm size, dan leverage.

Populasi dan Teknik Pemilihan Sampel. Perusahaan manufaktur dipilih karena jumlah industri manufaktur di BEI cukup untuk diambil sebagai sampel penelitian.Teknik yang digunakan untuk pengambilan sampel adalah purposive sampling dengan tujuan untuk mempermudah analisis dan mendapatkan sampel yang representatif sesuai dengan kriteria yang diinginkan. Kriteria perusahaan yang dijadikan sampel penelitian adalah: (a) Perusahaan manufaktur yang listing berturut-turut di BEI selama tahun 2013-2016. (b) Perusahaan yang tidak mengalami kerugian berturut-turut selama tahun 2013-2016. (c) Perusahaan yang data laporan keuangannya disusun dengan menggunakan mata uang rupiah. (d) Perusahaan yang menerbitkan laporan keuangan untuk periode yang berakhir 31 Desember selama periode 2013-2016. (e) Data yang dimiliki perusahaan lengkap.Informasi yang diperoleh kemudian diolah dan diuji dengan menggunakan software Eviews 6.0 untuk melihat hubungan antarvariabel.Analisis data yang digunakan regresi ganda non linier dengan software pengolahan data Eviews 9.

\section{HASIL DAN PEMBAHASAN}

Data penelitian menggunakan 61 sampel perusahaan manufaktur yang terdaftar di BEI sejak tahun 2013 sampai dengan 2016. Dengan menggunakan pendekatan panel data diperoleh keseluruhan data sebanyak 244 dengan statistik deskriptif dapat dilihat padatabel 1. Untuk $D A C R R$ nilai tertinggi sebesar 0,348604 dan terendah $-0,138427$ dengan ratarata nilai standard deviasi sebesar 0,083616 . Nilai institutional shareholding tertinggi sebesar 0,981786 dengan rata-rata 0,694763 dan standard deviasi sebesar 0,177881. Board independence tertinggi sebesar 1 dengan rata-rata 0,408360 dan standard deviasi sebesar 0,125688. Board size tertinggi sebesar 15 sedangkan rata-rata 5,393443 dan standard deviasi sebesar 2,671469 . Investment Opportunity Set tertinggi sebesar 28,44486 dengan rata-rata 2,700875 dan standard deviasi 4,256751. Firm size nilai tertinggi sebesar 14,41300 dan terendah dengan nilai 11,12640 standard deviasi sebesar 0,729481. Leverage nilai tertinggi sebesar 0,414536 dan terendah 0,006276 dengan nilai standard deviasi sebesar 0,091962. 
Berdasarkan pengujian regresi panel teridentifikasi sebagai berikut: menggunakan tingkat signifikansi 5\% pengaruh variabel independen relatif kuat pada board independen, firm size, dan investment opportunity set,sedangkan institutional shareholding dan board size dinilai memiliki pengaruh, tetapi pengaruhnya kurang kuat terhadap earnings quality. Karena satu variabel memiliki pengaruh kuat maka nilai $\mathrm{R}^{2}$ sebesar $2,8225 \%$ artinya earnings quality dipengaruhi board independen, firm size,investment opportunity set, institutional shareholding , dan board size sedangan 97,1775\% dipengaruhi faktor lain di luar. Dengan demikian nilai adjusted $\mathrm{R}^{2}$ juga relatif kecil hanya sebesar 7,967 \%.

Tabel 1. Statistik Deskriptif

\begin{tabular}{lccccccc}
\hline & DACCR & INST & BSIZE & BIND & MVBVA & SIZE & LEV \\
\hline Mean & 0.033072 & 0.694763 & 5.393443 & 0.408360 & 2.700875 & 12.32756 & 0.103564 \\
Median & 0.022318 & 0.707549 & 5.000000 & 0.333333 & 1.203337 & 12.16359 & 0.067720 \\
Maximum & 0.348604 & 0.981786 & 15.00000 & 1.000000 & 28.44486 & 14.41300 & 0.414536 \\
Minimum & -0.138427 & 0.224784 & 2.000000 & 0.200000 & 0.392326 & 11.12640 & 0.006276 \\
Std. Dev. & 0.083616 & 0.177881 & 2.671469 & 0.125688 & 4.256751 & 0.729481 & 0.091962 \\
Skewness & 0.848917 & -0.338924 & 1.174922 & 2.454785 & 3.993776 & 0.725127 & 1.303370 \\
Kurtosis & 4.236606 & 2.427031 & 4.137132 & 10.54770 & 20.23753 & 2.859912 & 4.015359 \\
Jarque-Bera & 44.85366 & 8.009013 & 69.28422 & 824.2283 & 3669.489 & 21.58243 & 79.56478 \\
Probability & 0.000000 & 0.018233 & 0.000000 & 0.000000 & 0.000000 & 0.000021 & 0.000000 \\
Sum & 8.069688 & 169.5221 & 1316.000 & 99.63990 & 659.0135 & 3007.925 & 25.26966 \\
Sum Sq. Dev. & 1.698949 & 7.688897 & 1734.230 & 3.838800 & 4403.142 & 129.3108 & 2.055063 \\
Observations & 244 & 244 & 244 & 244 & 244 & 244 & 244 \\
\hline
\end{tabular}

Tabel 2. Hasil Pengujian Regresi Panel Earnings Quality

\begin{tabular}{crrrr}
\hline \hline Variable & Coefficient & Std. Error & t-Statistic & Prob. \\
\hline \hline C & 0.042709 & 0.139657 & 0.305813 & 0.7600 \\
INST & -0.030103 & 0.038240 & -0.787206 & 0.4319 \\
BSIZE & 0.003223 & 0.003085 & 1.044953 & 0.2971 \\
BIND & -0.008965 & 0.051766 & -0.173184 & 0.8627 \\
MVBVA & $8.03 E-05$ & 0.001676 & 0.047886 & 0.9618 \\
SIZE & 0.001215 & 0.011590 & 0.104817 & 0.9166 \\
LEV & -0.170322 & 0.073725 & -2.310223 & 0.0217 \\
\hline \hline & Effects Specification & & \\
& & & S.D. & Rho \\
\hline \hline Cross-section random & & & 0.030149 & 0.1313 \\
Idiosyncratic random & & & 0.077564 & 0.8687 \\
\hline \hline & Weighted Statistics & \\
\hline \hline R-squared & 0.028225 & Mean dependent var & 0.026111 \\
Adjusted R-squared & 0.003623 & S.D. dependent var & 0.077815 \\
S.E. of regression & 0.077674 & Sum squared resid & 1.429889 \\
F-statistic & 1.147275 & Durbin-Watson stat & 1.497943 \\
Prob(F-statistic) & 0.335655 & & \\
\hline \hline
\end{tabular}


Unweighted Statistics

\begin{tabular}{llll}
\hline \hline R-squared & 0.041487 & Mean dependent var & 0.033072 \\
Sum squared resid & 1.628466 & Durbin-Watson stat & 1.315282 \\
\hline \hline
\end{tabular}

Pengujian Variabel institutional shareholding, board size, board independence, investment opportunity set, firm size, dan leverage terhadap earnings quality. Hipotesis tersebut dibuktikan oleh hasil regresi linier dengan hasil sebagai berikut:

Persamaan sebagai berikut:

DACCR $=0.042709-0.030103$ INST+0.003223 BSIZE -0.008965 BIND +0.001215

SIZE +

$$
0.00008038 \text { MVBVA - } 0.170322 \text { LEV }
$$

Keterangan:

$D A C C R=$ discretionary accrual (earnings quality); INST = institutional shareholding;

$B S I Z E=$ board size; BIND = board independence; $M V B V A=$ investment opportunity set;

$S I Z E=$ firm size; $L E V=$ leverage $; e=$ error .

1. Hipotesis Pertama. Hipotesis 1:Institutional shareholding berpengaruh negatif signifikan terhadap earnings quality.

Berdasarkan hasil pengujian Institutional shareholdingteridentifikasi nilai t sebesar negatif 0,787206 dengan probabilitas sebesar 0,4319 . Hasil tersebut berarti terdapat pengaruh negatif signifikan terhadap earning quality. Dengan demikian Hipotesis pertama diterima.

2. Hipotesis Kedua. Hipotesis 2: Board size berpengaruh signifikan terhadap earnings quality. Berdasarkan hasil pengujian board size teridentifikasi nilai t sebesar 1.044953 dengan probabilitas sebesar 0.2971 . Hasil tersebut berarti terdapat pengaruh positif signifikan terhadap earning quality, namun pengaruh tersebut tidak signifikan. Dengan demikian Hipotesis kedua diterima.

3. Hipotesis Ketiga. Hipotesis 3 :Board independence berpengaruh signifikan terhadap earnings quality. Berdasarkan hasil pengujian teridentifikasi Board independence nilai $\mathrm{t}$ sebesar negative -0.173184 dengan probabilitas sebesar 0.8627 . Hasil tersebut berarti terdapat pengaruh negatif signifikan terhadap earnings quality. Dengan demikian Hipotesis ketiga diterima.

4. Hipotesis Keempat, Hipotesis 4 :Investment Opportunity Set berpengaruh signifikan terhadap earnings quality. Berdasarkan hasil pengujian teridentifikasi Investment Opportunity Set nilai t sebesar 0.047886 dengan probabilitas sebesar 0.9618 . Hasil tersebut berarti terdapat pengaruh positif signifikan terhadap earnings quality. Dengan demikian Hipotesis keempat diterima.

5. Hipotesis Kelima. Hipotesis 5 :Firm size berpengaruh signifikan terhadap earnings quality. Berdasarkan hasil pengujian teridentifikasi Firm size nilai t sebesar 0.104817 dengan probabilitas sebesar 0.9166 . Hasil tersebut berarti terdapat pengaruh positif signifikan terhadap earnings quality. Dengan demikian Hipotesis kelima diterima.

6. Hipotesis Keenam. Hipotesis 6 :Leverage berpengaruh signifikan terhadap earnings quality. Berdasarkan hasil pengujian teridentifikasi Leverage nilai t sebesar negatif 2.310223 dengan probabilitas sebesar 0.0217 . Hasil tersebut berarti terdapat pengaruh negatif terhadap earnings quality, namun pengaruh tersebut tidak signifikan. Dengan demikian Hipotesis ketujuh ditolak. 
Berdasarkan hasil pengujian di atas dirangkum menjadi Tabel sebagai berikut:

Tabel 3. Tanda Hasil Pengujian Hipotesis

\begin{tabular}{llll}
\hline \multicolumn{1}{c}{ Variabel } & \multicolumn{1}{c}{ Simbol } & \multicolumn{1}{c}{ Tanda } & \multicolumn{1}{c}{ Keputusan } \\
\hline Institutional shareholding & INST & Negatif (Signifikan) & H1: Diterima \\
Board size & BSIZE & Positif (Signifikan) & H2: Diterima \\
Board independence & BIND & Negatif (Signifikan) & H3: Diterima \\
Investment Opportunity Set & MVBV & Positif (Signifikan) & H4 : Diterima \\
Firm size & SIZE & Positif (Signifikan) & H5 : Diterima \\
Leverage & LEV & Negatif & H6 : Ditolak \\
\hline
\end{tabular}

\section{PENUTUP}

Simpulan. Penelitian ini bertujuan untuk memperoleh bukti empiris mengenai pengaruh institutional shareholding, board size, board independence, investment opportunity set, firm size, dan leverage terhadap earnings quality yang diukur dengan discretionarry accruals pada perusahaan manufaktur perusahaan manufaktur yang terdaftar di Bursa Efek Indonesia tahun 2013-2015. Populasi yang digunakan dalam penelitian adalah seluruh perusahaan manufaktur yang terdaftar di Bursa Efek Indonesia selama tahun 2013-2015 yang berjumlah 148 perusahaan. Berdasarkan teknik purposive sampling, terdapat 69 perusahaan yang tidak memenuhi kriteria penelitian sehingga diperoleh 61 perusahaan untuk dijadikan sampel penelitian. Tahun penelitian diambil mulai tahun 2013 sampai dengan 2015 yang berjumlah tiga tahun. Oleh karena itu, jumlah penelitian sebanyak 61 perusahaan dikalikan tiga tahun menjadi 183 data sampel yang diambil untuk diteliti dalam penelitian ini.

Berdasarkan hasil analisis dan pengujian yang telah dilakukan, dapat disimpulkan bahwa terdapat pengaruh yang signifikan antara institutional shareholding dengan earnings quality yang diukur dengan discretionary accruals. Hasil penelitian ini konsisten dengan penelitian Muid (2009), Rupilu (2011), dan Houqe, et al. (2010) yang menjelaskan bahwa kepemilikan institusional yang tinggi mampu menurunkan tindakan manajemen laba dan menaikkan kualitas laba perusahaan Rachmawati dan Triatmoko (2007) serta Simamora, et al. (2014) yang mengatakan tidak adanya pengaruh yang signifikan antara kepemilikan institusional dengan kualitas laba. Akan tetapi hasil penelitian ini bertolak belakang dengan hasil penelitian.

Hasil penelitian juga menunjukkan adanya pengaruh yang signifikan antara variabel board size dengan earnings quality. Hasil penelitian ini konsisten dengan penelitian yang dilakukan Houqe, et al. (2010) yang menyebutkan bahwa ukuran dewan direksi yang semakin besar mampu meningkatkan efektivitas monitoring terhadap tindakan manajemen laba sehingga mampu meningkatkan kualitas laba perusahaan. Sebaliknya, hasil penelitian ini tidak mendukung penelitian yang dilakukan oleh Houqe, et al. (2010) yang menyebutkan bahwa ukuran dewan direksi yang semakin besar mampu meningkatkan efektivitas monitoring terhadap tindakan manajemen laba sehingga mampu meningkatkan kualitas laba perusahaan.

Board independence memiliki pengaruh yang signifikan terhadap earnings quality. Hasil ini konsisten dengan penelitian Siallagan dan Machfoedz (2006) yang mengatakan bahwa terdapat pengaruh yang signifikan antara proporsi dewan komisaris independen dengan kualitas laba. Akan tetapi hasil penelitian ini tidak sama dengan penelitian yang 
dilakukan oleh Rachmawati dan Triatmoko (2007), Muid (2009), Houqe, et al. (2010), Rupilu (2011), dan Simamora, et al. (2014) yang mengatakan bahwa proporsi dewan komisaris independen di suatu perusahaan hanya merupakan formalitas pemenuhan peraturan dan regulasi sehingga tidak berpengaruh baik terhadap manajemen laba maupun dengan kualitas laba perusahaan.

Investment opportunity set pengaruh yang signifikan terhadap earnings quality earnings quality yang diukur dengan discretionary accruals. Hal ini konsisten dengan penelitian yang dilakukan oleh Rachmawati dan Triatmoko (2007), Warianto dan Rustiti (2013), serta Sadiah dan Priyadi (2015) yang menyatakan bahwa tingginya tingkat investment opportunity set mampu memotivasi manajemen untuk melakukan tindakan manajemen laba sehingga kualitas laba perusahaan menjadi menurun. Akan tetapi hasil penelitian ini bertolak belakang dengan penelitian Simamora, et al. (2014) yang menjelaskan tidak adanya pengaruh yang signifikan antara peluang perusahaan untuk bertumbuh dengan kualitas laba.

Berdasarkan hasil analisis dan pengujian yang telah dilakukan, dapat disimpulkan bahwa terdapat pengaruh yang signifikan antara firm size dengan earnings quality. Hasil ini mendukung penelitian yang dilakukan oleh Warianto dan Rustiti (2013) serta Sadiah dan Priyadi (2015) yang menjelaskan bahwa ukuran perusahaan yang semakin besar menuntut manajemen untuk lebih berhati-hati dan cenderung menghindari manajemen laba sehingga diperoleh kualitas laba yang tinggi. Namun, hasil ini tidak sama dengan hasil penelitia Nasution dan Setiawan (2007) dan Mariana, Susilawati, dan Purwanto(2016) yang mengatakan bahwa tidak terdapat pengaruh yang signifikan antara ukuran suatu perusahaan dengan kualitas laba perusahaan tersebut.

Hasil penelitian juga menunjukkan adanya pengaruh namun tidak signifikan antara variabel leverage dengan earnings quality yang diukur dengan discretionary accruals. Hasil ini konsisten dengan penelitian Warianto dan Rustiti (2013) yang menyatakan bahwa tingkat leverage yang tinggi akan menunjukkan prospek masa depan perusahaan yang kurang baik sehingga memicu manajemen untuk melakukan manajemen laba dan kualitas laba perusahaan menjadi menurun. Akan tetapi hasil ini bertolak belakang dengan penelitian yang dilakukan oleh Sadiah dan Priyadi (2015) yang menjelaskan bahwa tidak terdapat pengaruh yang signifikan antara tingkat leverage suatu perusahaandengan kualitas laba perusahaan tersebut.

\section{DAFTAR RUJUKAN}

Boediono, Gideon. (2005). "Kualitas laba: studi pengaruh mekanisme corporate governance dan dampak manajemen laba dengan menggunakan analisis jalur". Simposium Nasional Akuntansi VIII. Solo. Hal. 172-194.

Dechow, Patricia, Weili Ge, dan Catherine Schrand. (2010). "Understanding earnings quality: A review of the proxies, their determinants and their consequences". Journal of Accounting and Economics. (50). hal. 344-401.

Dewi, Sisca Christianty. (2008). "Pengaruh kepemilikan managerial, kepemilikan institusional, kebijakan hutang, profitabilitas dan ukuran perusahaan terhadap kebijakan dividen”. Jurnal Bisnis dan Akuntansi. 10(1), 47-58.

Hermawan, Ancella Anitawati dan Galuh Nur Adinda. (2012). "The effect of board characteristics and audit committee existence on earnings quality of Indonesian state-owned enterprises". Journal of Accounting and Economics. 39(1), 329-360. 
Hodge, Frank D. (2003). "Investors' perception of earnings quality, auditor independence, and the usefulness of audited financial information". Accounting Horizons. 37-48.

Houqe, Muhammad Nurul, Tony van Zijl, Keitha Dunstan, dan A. K. M. Waresul Karim. (2010). "Does corporate governance affect earnings quality: Evidence from an emerging market". Business Management Review. 7(3). 1-12.

Liang, Jian dan Yuan George Shan. (2013). "Do corporate governance mechanisms impact on earnings quality? Evidence from IFRS adoption in the UK and Germany". 2013 Financial Markets and Corporate Governance Conference. hal. 1-41.

Mariana, Ana, R. Anastasia Endang Susilawati, Nanang Purwanto. (2016). "Pengaruh good corporate governance, leverage, dan ukuran perusahaan terhadap manajemen laba perbankan yang terdaftar di BEI". Jurnal Riset Mahasiswa Akuntansi (JRMA)Fakultas Ekonomi Universitas Kanjuruhan Malang. 4(1), 1-1.

Mojtahedzadeh, Vida, Seyed Hossein Alavi Tabari, dan Samane Shafiee. (2011). "The impact of strength and adequacy of corporate governance on earnings quality". Journal of Business and Economics. 2(3). 230-242.

Muid, Dul. (2009). "Pengaruh mekanisme corporate governance terhadap kualitas laba". Fokus Ekonomi. 4(2). 94-108.

Nathania, Aditha. (2014). "Pengaruh komposisi dewan perusahaan terhadap profitabilitas perusahaan". FINESTA. 2(1). 76-81.

Nasution, Marihot dan Doddy Setiawan. (2007). "Pengaruh corporate governance terhadap manajemen laba di industri perbankan Indonesia”. Simposium Nasional Akuntansi X. Makassar. hal. 1-26.

Novianti, Rizki. (2012). "Kajian kualitas laba pada perusahaan manufaktur yang terdaftar di BEI". Accounting Analysis Journal. 1(2). 1-6.

Peraturan Menteri Negara Badan Usaha Milik Negara Nomor: PER-01/MBU/2011 tentang penerapan tata kelola perusahaan yang baik pada badan usaha milik negara.

Prastiti, Anindyah dan Wahyu Meiranto. (2013). "Pengaruh karakteristik dewan komisaris dan komite audit terhadap manajemen laba". Diponegoro Journal of Accounting. 2(4), 1-12.

Rachmawati, Andri dan Hanung Triatmoko. (2007). Analisis faktor-faktor yang mempengaruhi kualitas laba dan nilai perusahaan. Simposium Nasional Akuntansi X. Makassar. hal. 1-26.

Rupilu, Wilsna. (2011). "Pengaruh mekanisme corporate governance terhadap kualitas laba dan nilai perusahaan pada perusahaan manufaktur yang terdaftar di bursa efek Indonesia". Jurnal Akuntansi, Manajemen Bisnis, dan Sektor Publik (JAMBSP). $8(1), 101-127$.

Sadiah, Halimatus dan Maswar Patuh Priyadi. (2015). "Pengaruh leverage, likuiditas, size, pertumbuhan laba dan IOS terhadap kualitas laba". Jurnal Ilmu dan Riset Akuntansi. 4(5). 1-21.

Setianingsih, Lestari. (2016). "Pengaruh investment opportunity set, likuiditas, dan good corporate governance terhadap kualitas laba pada perusahaan". Jurnal Ilmiah Mahasiswa S1 Akuntansi Universitas Pandanaran. 2(2). 1-17.

Siallagan, Hamonangan dan Mas'ud Machfoedz. (2006). "Mekanisme corporate governance, kualitas laba, dan nilai perusahaan". Simposium Nasional Akuntansi IX. Padang. hal. 1-23.

Simamora, Erikson, Amries Rusli Tanjung, dan Julita. (2014). "Pengaruh investment opportunity set (IOS), mekanisme good corporate governance, dan reputasi KAP 
terhadap kualitas laba perusahaan (studi empiris pada perusahaan property dan real estate yang terdaftar di bursa efek indonesia 2010-2012)". Jurnal Online Mahasiswa Fakultas Ekonomi Universitas Riau (JOM FEKON). 1(2), 1-21.

Sivaramakrishnan, K. dan Shaokun Carol Yu. (2008). On the association between corporate governance and earnings quality. AAA 2008 Financial Accounting and Reporting Section (FARS) Paper. hal. 1-36.

Syarif, Firman dan Daniel Anka Utama Pasaribu. (2015). Pengaruh tingkat konvergensi IFRS dan perlindungan bagi investor terhadap kualitas laba pada perusahaanperusahaan yang terdaftar di bursa efek negara: Indonesia, Malaysia, Singapura, dan India. Simposium Nasional Akuntansi XVIII. Medan. hal. 1-22.

Terzaghi, Muhammad Titan. (2012). "Pengaruh earning management dan mekanisme corporate governance terhadap pengungkapan tanggung jawab sosial perusahaan manufaktur yang terdaftar di bursa efek Indonesia". Jurnal Ekonomi dan Informasi Akuntansi (JENIUS). 2(1). 31-47.

Ujiyantho, Muh. Arief dan Bambang Agus Pramuka. (2007). Mekanisme corporate governance, manajemen laba, dan kinerja keuangan. Simposium Nasional Akuntansi $X$. Makassar. hal. 1-26.

Wardhani, Ratna. (2009). "Pengaruh proteksi bagi investor, konvergensi standar akuntansi, implementasi corporate governance, dan kualitas audit terhadap kualitas laba: Analisis lintas negara di Asia". Disertasi Dipublikasikan Program Doktor Ilmu Akuntansi Universitas Indonesia. Jakarta

Warianto, Paulina dan Rustiti. (2013). "Pengaruh ukuran perusahaan, struktur modal, likuiditas dan investment opportunity set (IOS) terhadap kualitas laba pada perusahaan manufaktur yang terdapat di BEI". E-Journal Universitas Atma Jaya Yogyakarta. hal. 1-15.

Wulandari, Ndaruningpuri. (2006). "Pengaruh indikator mekanisme corporate governance terhadap kinerja perusahaan publik di Indonesia". Fokus Ekonomi. 1(2), 120-136.

Wulansari, Yenny. (2013). "Pengaruh investment opportunity set, likuiditas, dan leverage terhadap kualitas laba pada perusahaan manufaktur yang terdaftar di BEI". EJournal Universitas Negeri Padang. hal. 1-31.

Yaghoobnezhad, Ahmad, Hashem Nikoomaram, dan Haydar Mohammadzadeh Salteh. (2012). "The investigation of relationship between corporate governance and earnings quality". Journal of Business Management. 6(11), 3898-3912. 